\title{
THE THOMAS A. EDISON PAPERS: \\ PUBLISHING THE RECORDS \\ OF AN AMERICAN GENIUS
}

\author{
$B Y$ THOMAS E. JEFFREY
}

Dr. Jeffrey is Associate Editor and Microfilm Editor, Thomas A. Edison Papers

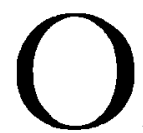

N FEBRUARY I I, I985-the I 38 th anniversary of the birth of Thomas Alva Edison-the editors of the Thomas A. Edison Papers officially announced the publication of The Thomas A. Edison Papers: A Selective Microfilm Edition, Part $I(I 850-I 878)$, the first of a projected six-part edition of the papers of America's most prolific inventor. ${ }^{I}$ With the publication of this pathbreaking microfilm edition, scholars now have entree into the laboratory notebooks, correspondence, legal records, and other historically significant papers relating to Edison's early career as an inventor, manufacturer, and entrepreneur.

Rutgers University has been intimately involved with the editing of Edison's papers since 1978, when the University was formally designated as one of the project's four cosponsors, along with the National Park Service, the New Jersey Historical Commission, and the Smithsonian Institution. That same year Dr. Reese V. Jenkins, a nationally known historian of science, technology, and business, was appointed director and editor of the papers and professor of history at Rutgers. Since that time the main editorial office of the Thomas A. Edison Papers has been located on the College Avenue Campus, and its large staff of professional editors have served concurrently as full-time or adjunct members of the History Department faculty. For the past five years the Rutgers University Foundation has played a major role in providing the project with a sound financial foundation through its extensive private fund-

\footnotetext{
I Thomas E. Jeffrey et al., Thomas A. Edison Papers: A Selective Microflim Edition, Part $I$ ( $1850-1878$ ) (Frederick, Md., University Publications of America, 1985) [hereinafter referred to as TAE Papers Microfilm Ed.]. Information regarding the purchase of this microfilm edition and its accompanying guide may be obtained by writing to University Publications of America, Inc., 44 North Market Street, Frederick, Md. 2 I 7 O I. Information regarding interlibrary loan of this edition may be obtained by writing to Reference Desk, Special Collections and Archives, Rutgers University Libraries, New Brunswick, N.J. 08903.
} 


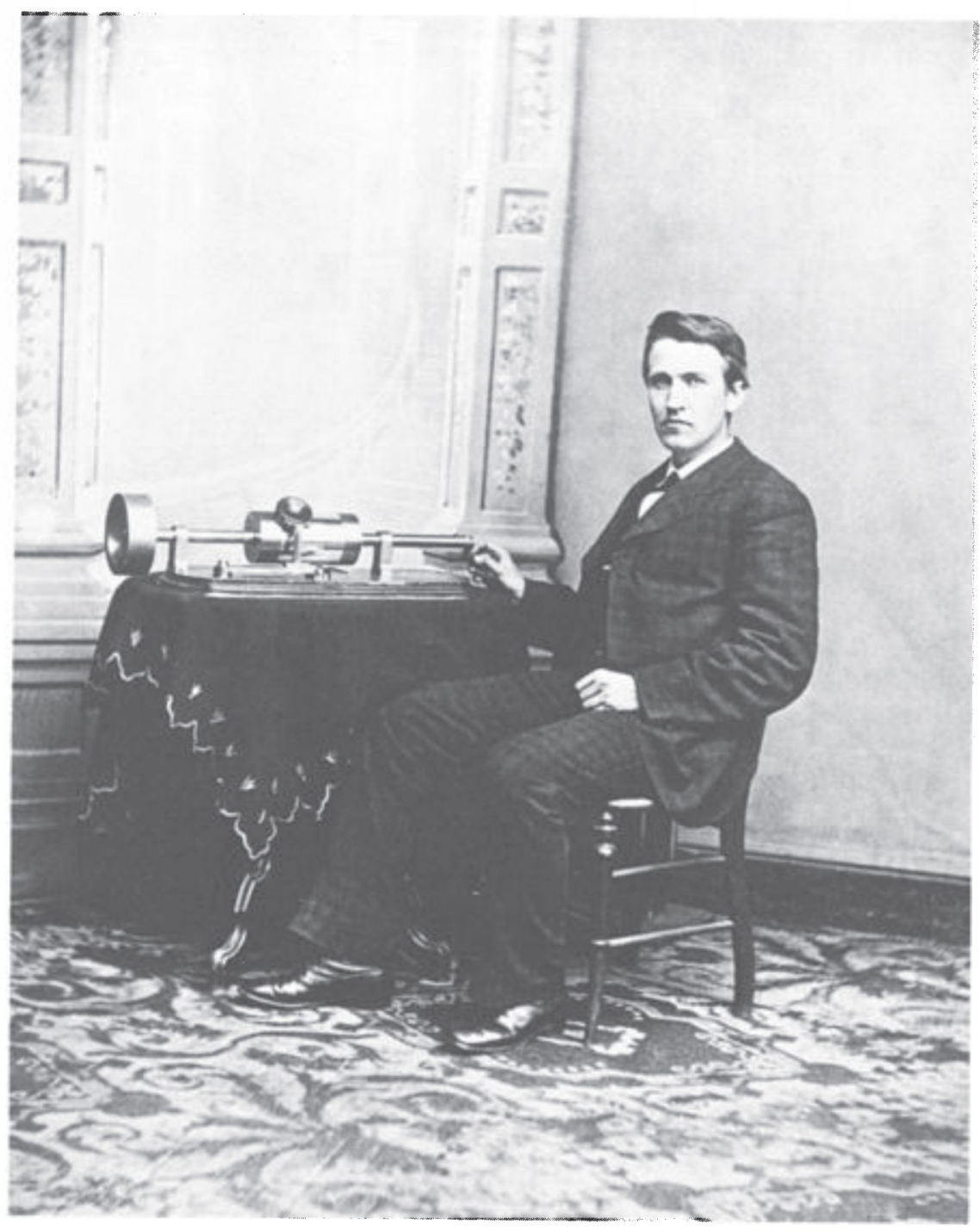

EDISON WITH HIS PHONOGRAPH. ITS INVENTION IN 1877 BROUGHT EDISON WORLDWIDE RENOWN. THIS PHOTOGRAPH WAS TAKEN BY MATHEW BRADY IN 1878, WHEN EDISON VISITED WASHINGTON, D.C. TO DEMONSTRATE HIS INVENTION TO PRESIDENT RUTHERFORD HAYES AND TO MEMBERS OF CONGRESS. (Courtesy of the Edison National Historic Site) 
raising campaign. The Foundation's staff have also worked closely with the Edison Corporate Associates and its chairman, William C. Hittinger of the RCA Corporation, who have been soliciting corporate support for the project. ${ }^{2}$ The Rutgers University Library will now be joining this cooperative endeavor in its capacity as the official repository for the master negative and for the interlibrary loan copy of the microfilm edition.

Although the editors plan eventually to microfilm significant material from a variety of repositories in the United States and Western Europe, the documents presented in Part I are all from the archives at the Edison National Historic Site in West Orange, New Jersey. This historic landmark, which served as Edison's main laboratory from I 887 until his death in I93 $\mathrm{I}$, is now maintained by the National Park Service as a museum and a visitor center. Its archives contain more than 3-1/2 million pages of manuscripts, over 20,000 photographs, and an extensive collection of experimental and production models of Edison's inventions. Until quite recently, however, the enormous size of these archives and their organizational complexity have deterred researchers from delving extensively into their wealth of documentary resources.

The microfilm edition, whose segments will be published at three-year intervals, will eventually contain about 400,000 pages of documents - approximately io percent of the total number known to exist. Because the quantity of material for the first decade of Edison's inventive career (1 868-1878) is relatively small, nearly all of it has been filmed in Part I. These twenty-eight reels of microfilm contain approximately 40,000 pages of documentsroughly 90 percent of the total documentation at the West Orange archives for this time period. Subsequent parts of the microfilm edition will be much more selective, but there will be numerous references on the film to related material that was not selected for inclusion. The microfilm edition will thus serve not only as a documentary resource for Edison's most important papers but also as an important entree into the larger collection.

\footnotetext{
${ }^{2}$ In addition to Mr. Hittinger, the following individuals have served as members of the Edison Corporate Associates: Arthur M. Bueche, General Electric; Frank J. Biondi, Jr., Coca-Cola; Edward J. Bloustein, Rutgers; Cees Bruynes, North American Philips; Paul J. Christiansen, Charles Edison Fund; Philip F. Dietz, Westinghouse Electric; Paul Lego, Westinghouse Electric; Roland W. Schmitt, General Electric; Robert I. Smith, PSE\&G; Harold W. Sonn, PSE\&G; Morris Tanenbaum, AT\&T.
} 


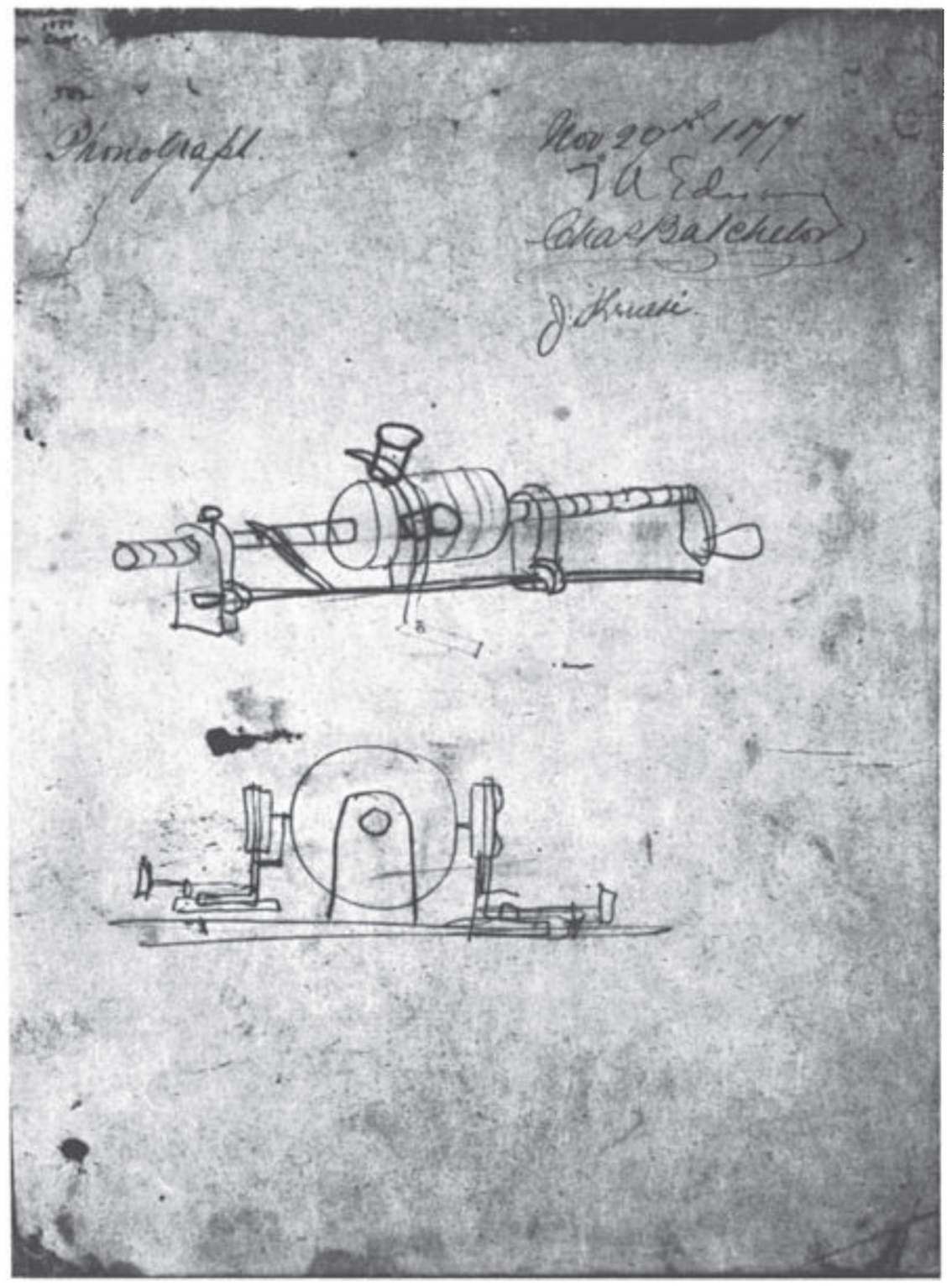

THIS DRAWING OF THE PHONOGRAPH, MADE ON NOVEMBER 29, 1877, SHOWS EDISON'S FINAL DESIGN FOR THE MACHINE CONSTRUCTED BY JOHN KRUESI, HIS MASTER MECHANIC. (Courtesy of the Edison National Historic Site) 
The richness, quantity, and diversity of materials in the Edison archives at West Orange make this edition of his papers of interest to a wide range of scholars. Edison's laboratory notebooks, replete with beautifully executed sketches and drawings, provide insight into the mind of America's best-known inventor, elucidate his inventive method, and reveal the contributions made by his numerous laboratory associates. At the same time, the correspondence, agreements, legal papers, and other business records document Edison's involvement with America's most powerful industrialists and financiers and illuminate the operations of his own factories and businesses. In a larger sense, Edison's papers offer scholars an important resource for understanding the transformation of the United States from a rural-agrarian nation to an urban-industrialcorporate society. Historians of technology, science, business, labor, and popular culture will all find an abundance of documentary riches in the microfilm edition.

Although Edison is best known today for his work on electric lighting, many of his earliest innovations were in the field of telegraphy. Since the I 85 os the telegraph had served as the most important means of rapid communication for government and business, and the country's most talented inventors sought ways to make Morse's instrument more reliable and efficient. Edison's work on the stock printer and the automatic telegraph (the forerunner of today's teletype), along with his contributions to multiple telegraphy (the transmission of two or more messages simultaneously across the wire), made him an important figure in the technological community even before his invention of the phonograph brought him worldwide renown in 1878 .

Edison began his career as an itinerant telegrapher, and in the years during and immediately after the Civil War he worked as a telegraph operator in several cities in the Midwest and the South. In I 868 he moved to Boston, which was then one of the country's technological centers. After working less than a year as a telegraph operator for Western Union, Edison resigned his position in order to become an independent inventor. Self-employment did not, however, result in total independence. Although he was now on his own, Edison still relied on the financial resources of outside investors, who were willing to bankroll his activities in exchange for legal rights to his patents. There is evidence that this arrangement 
did not always please the young inventor. One of his earliest technical notebooks, for example, contains the following notation: "Daily record of ideas. . . . Invented for myself exclusively, and not for any small brained capitalist." 3

As early as the summer of I 868 the twenty-one year old Edison had made the first of several agreements with Ebenezer B. Welch, a Boston businessman, to finance his work in telegraphy. After moving to New York City in I 869 , Edison became a consulting engineer for the Gold \& Stock Telegraph Company, which at the time had a virtual monopoly on the business of providing price quotations to stockbrokers in the nation's financial capital. In February 1870 , shortly before moving to Newark, he received funds from two Gold \& Stock executives to set up the Newark Telegraph Works, his first major shop. During the early i 870 os Edison and his associates established several other shops in Newark to manufacture telegraph equipment and develop new inventions. ${ }^{4}$

Edison's manufacturing enterprises helped provide the financial resources necessary for his inventive activity. Edison also procured funds for his experiments by obtaining contracts from telegraph companies to develop new inventions. The decade of the $1870 \mathrm{Os}$ witnessed intense competition between Western Union and its rivals for control of the telegraph industry, and each company sought to control the patents on major new systems of telegraphy in order to gain an advantage over its competitors. Edison was fully aware of this competitive marketplace, and he signed contracts with several rival companies. At the same time that he was negotiating with Western Union to develop duplex telegraphy (sending two messages simultaneously across the wire), Edison also made an arrangement with another company to work on a method of sending and recording telegraph messages automatically by means of punched paper tape. By I 875 Edison's system of automatic telegraphy had been adopted by the Atlantic \& Pacific Telegraph Company, an organization controlled by Jay Gould.

3 Notebook, Cat. 1172, July 29, I87 I, TAE Papers Microfilm Ed., 3:78.

4 The best biography of Edison is still Matthew Josephson, Edison: A Biography (New York: McGraw Hill, 1959). Relatively little is known about the early part of Edison's career. For a brief, but accurate, account of Edison's early years, see Reese V. Jenkins and Paul B. Israel, "Thomas A. Edison: Flamboyant Inventor," IEEE Spectrum (December I 984), pp. 74-79. The discussion here and in the following paragraphs is based predominantly on the information contained in this essay. 


\section{RUTGERS UNIVERSITY LIBRARIES}

Western Union met this challenge by adopting the system of multiple telegraphy that had been perfected by Edison and others. The struggle for control of the telegraph industry was eventually carried into the courts, when Atlantic \& Pacific sued Western Union over the ownership of Edison's patents on quadruplex telegraphy (sending four messages simultaneously across the wire). By the time the Quadruplex Case was adjudicated in 1878 , the

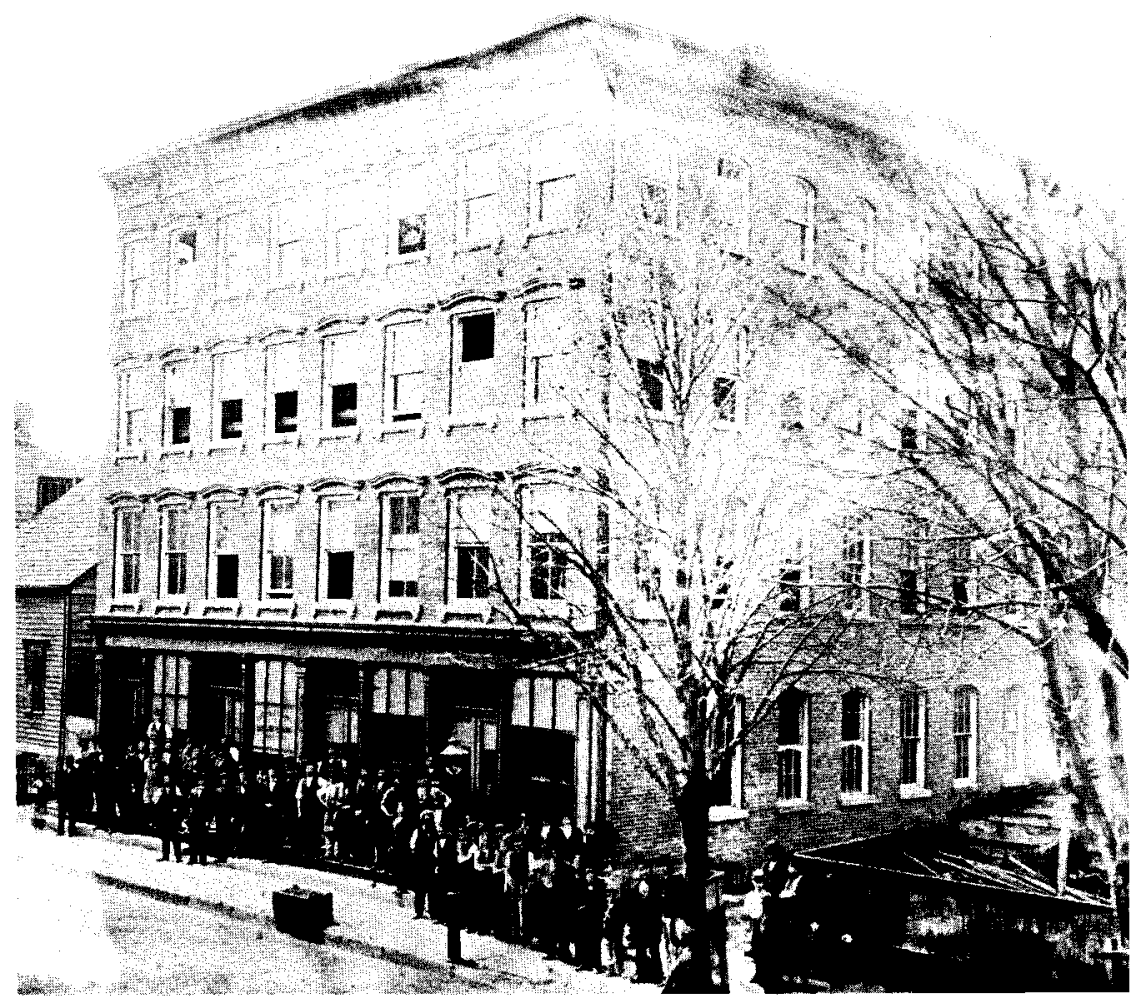

IN 1870 EDISON RECEIVED FUNDS FROM TWO EXECUTIVES OF THE GOLD \& STOCK TELEGRAPH COMPANY TO SET UP THE

NEWARK TELEGRAPH WORKS. THIS PHOTOGRAPH WAS PROBABLY

TAKEN IN 1872, AFTER THE FIRM HAD MOVED TO WARD STREET

(NOW MCCARTER HIGHWAY) AND HAD CHANGED ITS NAME

TO EDISON \& UNGER. (Courtesy of the Edison National Historic Site) 
competing interests had already settled their differences out of court. However, the extensive testimony by Edison and his associates, along with the technical drawings, agreements, and other documents that were submitted as exhibits, provide important documentation of the inventive activity in Edison's Newark and Menlo Park laboratories during the I 870 . Indeed, in many cases, the facsimiles and transcripts found in these printed records constitute the only surviving record of these documents.

In the spring of I 876 Edison left Newark and moved to Menlo Park, where he had built a laboratory with money received from a lucrative new contract with Western Union. Charles Batchelor, John Kruesi, John Ott, and other associates, who had worked with Edison since his early days at Newark, moved with him to Menlo Park, and the inventor soon acquired the services of other talented young men, such as Francis Upton and William S. Andrews. Edison referred to his new laboratory as his "invention factory." Historians of technology have characterized it as one of the first industrial research laboratories in the world, the forerunner of Bell Laboratories and numerous other corporate think tanks. Edison boasted that he planned to come up with a minor invention every ten days and a major one every six months. Incredibly, he managed to keep up with that pace. During his years at Menlo Park Edison received an average of one patent every nine days. By the end of 1878 he had invented the phonograph, developed the carbon-button transmitter (still one of the basic mechanisms of the telephone), and commenced the experiments that eventually led to the first practical incandescent lamp.

All of these activities are documented in Part I of the microfilm edition. Part II, which is currently being prepared for filming, will focus on Edison's invention of the incandescent light, his role in the creation and promotion of centralized systems for the production and distribution of electric power, and his establishment of multinational corporations to manufacture and market the electric light and telephone. The remaining four parts of the microfilm edition will document Edison's inventive and business activities in West Orange during the years I 887-I93 I and will treat such subjects as the invention of motion pictures, the perfection of the alkaline storage battery, Edison's ill-fated ore-milling venture, and the formation of Thomas A. Edison, Inc. 
The documents presented in Part I appear on the microfilm in ten series that parallel existing record groups within the archives at the Edison National Historic Site. The Notebook Series (six reels) contains a variety of technical records ranging from large ledgersized volumes to small pocket notebooks to rough notes and drawings on loose pieces of paper. Although Edison began his career as a professional inventor in 1869 , he apparently did not attempt to keep systematic records of his experiments until several years later. A pocket notebook from late 1870 , which Edison used to enter specifications and drawings for printing telegraph apparatus, concluded with a resolution that "I will here after keep a full record." 5

This determination to keep a full record of inventive activity soon led to the creation of more than a dozen technical notebooks, many of them containing beautiful drawings. In addition to serving as a record of his experimental work, Edison's notebooks were also important legal documents. In anticipation of patent and contractual litigation, Edison and his associates signed, dated, and witnessed many of the notebook entries.

Most of Edison's early notes and drawings relate to telegraphy, telephony, and electric lighting, but there is also material on the phonograph, the electric pen (the precursor of the mimeograph), etheric force (a scientific discovery that was later recognized as radio waves), ore mining, batteries, and numerous other topics. These documents, which have rarely been used by scholars, reveal the incredible range of Edison's interests. One notebook, for example, contains ideas for inventions such as a pocket spectroscope, an electric shear, an artificial fragrant rose, and a flying bird. ${ }^{6}$

Supplementing the Notebook Series is a small Patent Series (one reel) containing patent applications and caveats (preliminary applications) for several of Edison's telegraph inventions. Also included in this series are abstracts of more than one hundred of Edison's unsuccessful patent applications, compiled by William $\mathrm{H}$. Meadowcroft, the inventor's longtime secretary, along with certified copies of seven abandoned applications relating to multiple telegraphy. Although Edison received more U.S. patents than any other inventor, many of his ideas did not lead directly to patentable

5 Notebook, PN-70-10-03, TAE Papers Microfilm Ed., 6:819.

6 Notebook, Cat. 997, TAE Papers Microfilm Ed., 3:35 I. 
inventions. Yet a full understanding of Edison's inventive activity requires an awareness of the wrong directions and blind alleys, as well as the paths of endeavor that ultimately led to success. The caveats and unsuccessful applications presented in this series thus constitute an important adjunct to the laboratory notebooks as source material for understanding the evolution of Edison's technical ideas.

The Document File Series (eight reels) is an extensive collection of incoming correspondence and other unbound documents, such as agreements, incorporation papers, promissory notes, bills, and some outgoing correspondence. Much of the incoming correspondence contains marginal notes by Edison or one of his secretaries, indicating the nature of the reply. The documents are organized by year and by subjects within each year. In many respects, the Document File-along with the laboratory notebooks-constitutes the core of the Edison collection.

The earliest correspondence, dating from I 869 , consists of a series of letters from Edison to Frank Hanaford, his former business partner in Boston. At the time these letters were written, Edison-only twenty-two years old-had just arrived in New York City, penniless and without a job. "No matter what I may do I reap nothing but Trouble, and the blues," the disconsolate young inventor told his friend in July. ". . . It is all I can do to keep the wolf from the door." 7 By 1875 , thanks to his lucrative contracts with Western Union and other telegraph companies, Edison was already on his way to wealth and fame. One document from that year bears the interesting title, "Plans for paying much from nothing." In it the inventor listed eleven different ways by which he and his associates could make money from the sale of his automatic telegraph system. ${ }^{8}$ This document provides conclusive evidence that, even at this early stage of his career, Edison was thoroughly familiar with the intricacies of stock manipulation and other nineteenth-century business practices.

By I 878 , as a result of his invention of the phonograph, Edison's name had become a household word, and an admiring press was already dubbing him the "Wizard of Menlo Park." Not surprisingly, this newfound fame resulted in a substantial increase in the volume of Edison's mail, as the inventor was deluged with fan mail

7 TAE to Frank Hanaford, July 26, I869, TAE Papers Microfilm Ed., I 2:23.

8 "Plans for paying much from nothing," [1875], TAE Papers Microfilm Ed., 13:507. 


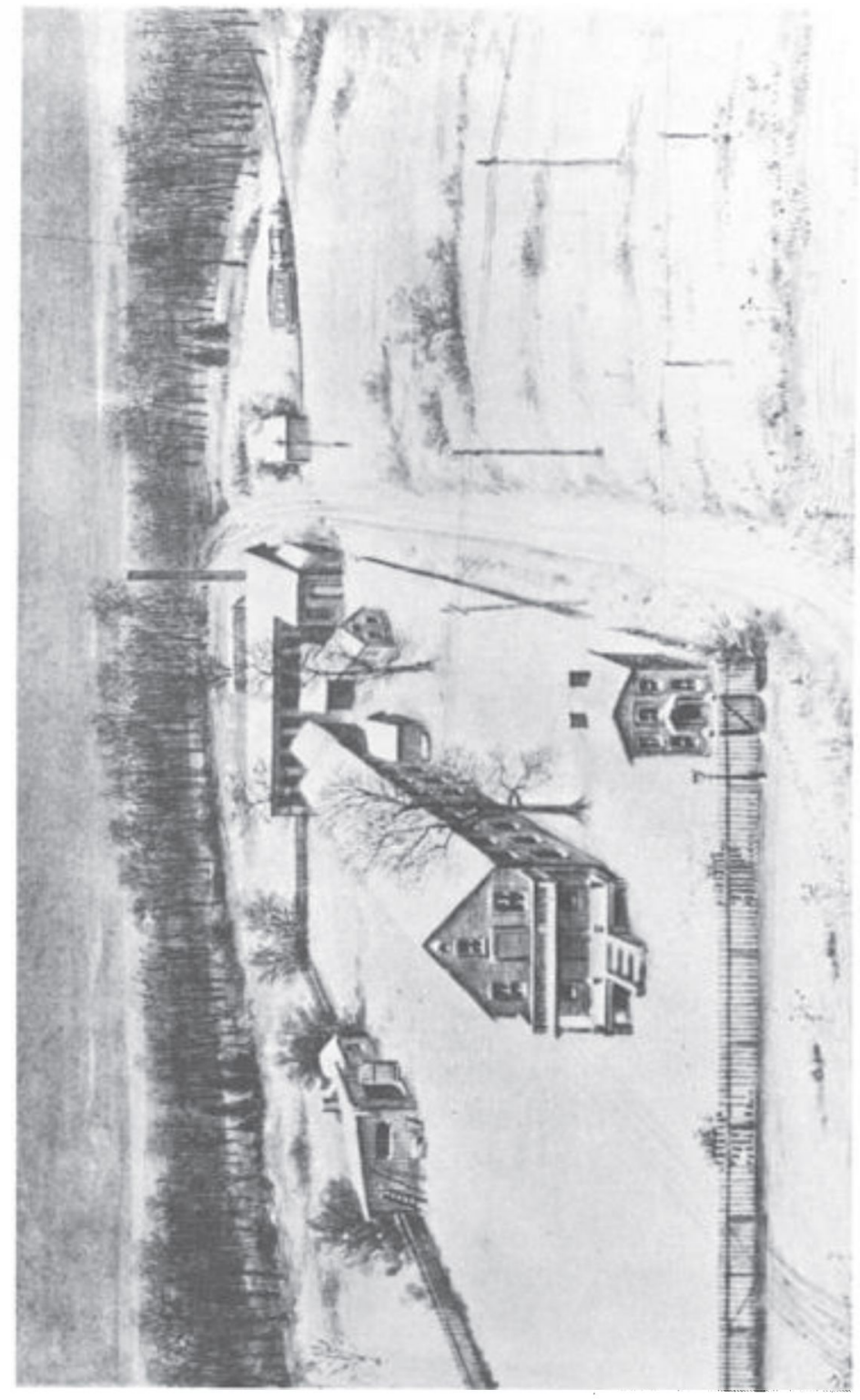

Z亩至

我足

出㟔先。

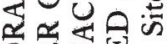

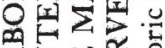

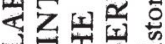
出的证

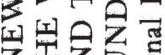
乙现至。

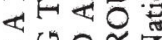

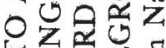
곤된 둥 되 目是红结

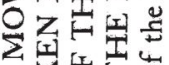
㟔出

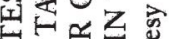

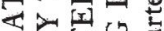

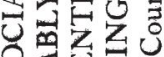
○究红 为行四 -

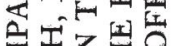
配台诖

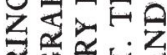

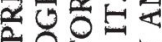

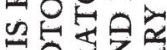

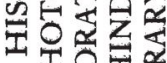

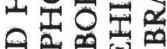
음 近四 踏公

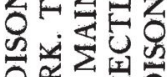

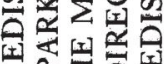

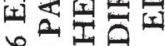
이 $\infty-\infty$

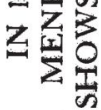


and letters seeking advice or requesting information about his inventions. Some of Edison's admirers apparently expected the inventor to use his ingenuity to solve their personal problems. For example, one lovesick young man wrote Edison that he hoped to attain his heart's desire by inventing something useful. "I beg of you in all earnestness to give me some encouragement to gain my heart's love. ... and dear Professor I thank you with my whole soul if you can help me in my purpose."9 Letters like this reveal much about popular perceptions of Edison, and a sample of them has been included in the microfilm edition.

Two smaller collections - the Letterbook Series and the Legal Series (one reel) - form an important adjunct to the Document File. Edison did not begin keeping letterpress copies of his outgoing correspondence until I 875 , and much of the material in the earliest letterbooks relates to routine business matters. However, there are numerous letters of considerable importance scattered throughout the books, as well as copies of patent applications and tests of Edison's duplicating inks. The Legal Series consists of two files maintained by Harry F. Miller and Richard W. Kellow, who worked for Edison around the turn of the century. Both of these collections contain contracts, deeds, leases, powers of attorney, and other important documents that provided the legal underpinning for Edison's business activities.

The Litigation Series (three reels) contains printed court and Patent Office records relating to multiple telegraphy and to the invention of the telephone. These documents provide valuable information about Edison's role as an inventor and manufacturer of telegraph instruments, his contribution to the development of the telephone, the operations of his Newark and Menlo Park laboratories, and the multifarious financial arrangements that supported his inventive and business activities.

The Account Series (three reels) contains over seventy-five volumes of business records relating to the operations of Edison's three Newark shops-the American Telegraph Works, Edison \& Unger, and Edison \& Murray. There are also records relating to Edison's personal finances and items recording the expenditures of Edison, his family, and members of his staff on groceries and

9 William T. Leslie to TAE, June 12, I878, TAE Papers Microfilm Ed., i6:660. 
household commodities. This series also contains an extensive run of cost accounts that document the rate of pay and number of hours worked by each employee, as well as the cost of tools and supplies. In addition to documenting Edison's business activities, the accounts also provide valuable information about Edison's technical work, such as the production costs of experimental models.

The Menlo Park Scrapbook Series (four reels) consists of fiftyseven scrapbooks containing clippings from a variety of technical journals, popular magazines, and newspapers. Together with the eleven scrapbooks in the Miscellaneous Scrapbook Series (one reel), these volumes constitute an important resource for studying the technological, scientific, and cultural context within which Edison and his associates lived and worked.

Introducing this microfilm edition of Edison's earliest papers are two reels containing a complete set of Edison's I,093 U.S. patents. Although these patents span the years I 869-I 933 and thus cut across the six chronological parts of the microfilm edition, the editors decided to film them at once in their entirety both to preserve the integrity of the collection and to make these important materials immediately accessible to researchers.

If the microfilm edition contained nothing more than a carefully organized selection of the most significant Edison documents, that alone would make it an invaluable resource for scholars. However, the editors have also included numerous finding aids to assist the reader in using the materials in the collection. For example, the edition contains more than five hundred pages of editorial "targets" that introduce each major series and characterize the contents of the individual volumes and folders. The targets also include numerous cross-references to direct the researcher to related material. For example, one of Edison's notebooks contains almost one hundred pages of notes and drawings relating to the electric light, which were copied into the book by William Carman, Edison's bookkeeper. The target to that volume points out that the original drawings can be found in two other notebooks, so that the researcher can, if he wishes, refer back to the originals. ${ }^{10}$

Sometimes the targets are used to identify related material in several different series. For example, the target to one of Edison's

${ }^{\circ}$ Notebook, Cat. 996, TAE Papers Microflm Ed., 3:278. 
account books mentions a series of cost accounts for research on various inventions and points out that a similar list of inventions can be found in the Notebook Series. " series of unbound notebooks, numbered as Volumes 8 to I 8 , informs the reader that many of the drawings and notes in this set were removed for use as exhibits in a Patent Office proceeding and were never returned to Edison. The target goes on to point out that facsimiles of most of these missing documents appear in the printed record of Edison exhibits in the Litigation Series. By correlating the numbered drawings in the two series, the researcher can reconstruct the original numerical sequence. ${ }^{12}$

On occasion the editors have actually constructed "new" documents from materials that were previously scattered throughout the archive. In the Notebook Series, for example, there is a set of nearly 300 pages of notes and drawings that contain drafts of several essays by Edison on telegraphy and electricity. These undated materials had previously been filed in dozens of different subject folders over a wide range of years. The editors also discovered that numerous individual pages that belonged in this set had subsequently been pasted into several of Edison's scrapbooks. In such cases, photocopies of the scrapbook pages were filmed with the unbound materials in order to complete the set. A target preceding the set explains the organizational system and contains cross-references to the technical journals in which some of these essays were eventually published. ${ }^{13}$

In addition to the targets and other finding aids that appear on the film itself, the microfilm edition is accompanied by a clothbound printed guide of approximately I 50 pages. The guide contains a history of Edison's papers, a chronology of his life, a discussion of editorial principles, descriptions and contents lists for each of the series, and, most important, indexes that provide direct access to the documents in the microfilm edition. Under the direction of Dr. Leonard S. Reich, the associate project director, a computerized retrieval system was developed to allow the editors to search for documents with any combination of specific characteristics such as authors, recipients, dates, and subjects. At the same time, a com-

"Edison \& Murray Accounts, Cat. 1214, TAE Papers Microfilm Ed., 2 I:562.

12 TAE Papers Microfilm Ed., 3:427.

13 Unbound Notes and Drawings, NS-74-002, TAE Papers Microfilm Ed., 7:42. 


\section{RUTGERS UNIVERSITY LIBRARIES}

puter program was also created to generate from the Edison Papers database the three indexes that are published in the printed guide.

The Index to Authors and Recipients enables the researcher to easily locate all the letters that were exchanged between Edison and any other correspondent. Under the entry "GOULD, Jay," for example, there is a list of six letters written by Edison to Gould, and another six letters from Gould to Edison. Immediately following is a list of agreements, powers of attorney, and other noncorrespondence that Gould either authored or signed. In each case, the index directs the reader to the reel and frame containing the first page of the document.

Certain categories of documents, such as accounts, bills and receipts, and orders, were indexed in groups rather than individually. The Index to Financial Documents guides the researcher to the beginning of the appropriate folder or volume containing the financial material. For example, the entry for "Accounts" reveals that accounting records for the year I 873 may be found in thirteen individual folders and volumes on five reels of microfilm.

Of special interest to historians of technology is the Chronological Index to Technical Notes and Drawings. In addition to listing dated entries in the laboratory notebooks, this index also includes references to technical material appearing as exhibits in court cases, as occasional entries in account books and letterbooks, and as items pasted into the scrapbooks. For example, a researcher interested in the activities of the laboratory on September 9, I 878 can use the index to find references to seven sets of notes and drawings on four different reels of microfilm. By thus bringing together material that is widely scattered in its original form, this index serves as a powerful bibliographical tool.

As mentioned earlier, the microfilm edition of the Thomas A. Edison Papers is intended, in part, to serve as an entree into the larger corpus of documents in the archives at the Edison National Historic Site. A vast quantity of material at the Edison archives relates to the operations of Edison's factories in West Orange and nearby communities. Although most of these documents fall outside the scope of the microfilm edition, they may be of considerable importance to those interested in community history. For example, we currently know very little about the impact of Edison's industries on the political, economic, social, and cultural life of the West 
Orange community. The materials in the Edison archives offer a rich, but hitherto neglected, resource for the study of this question as well as numerous other issues in local history.

New Jersey was the home of Thomas A. Edison for over fiftyfive years, and the Garden State was one of the first to feel the effect of his work in electric lighting, electric power distribution, ore milling, cement manufacturing, and motion picture production. Yet we still know little about how Edison's activity influenced the economic, social, and political development of New Jersey during the late nineteenth and early twentieth century. It is hoped that the publication of the microfilm edition of the Thomas A. Edison Papers will acquaint students of New Jersey history with the wealth of material available at the Edison archives and will thus stimulate further research.

In addition to the microfilm edition, the editors will be publishing a hardbound edition of annotated Edison papers, estimated to run between fifteen and twenty volumes, and a variety of illustrated books, slides, and films. Together, these publications will be of interest to specialized scholars, general historians, and a broad segment of the American public. By making a significant portion of Edison's work available for the first time, the publication of his papers will help us to understand the emergence of industrial America and the life of one of history's true giants. 